\title{
Effect of feeding Artemia nauplii enriched with different enhancement products on larval performance of golden pompano Trachinotus ovatus (Linnaeus, 1758)
}

\author{
ZHENHUA MA ${ }^{1,2}$, PANLONG ZHENG ${ }^{1,3}$, DAN HE ${ }^{1,3}$, SHIGUI JIANG1 AND JIAN G. QIN ${ }^{4}$ \\ ${ }^{1}$ South China Sea Fisheries Research Institute, Chinese Academy of Fishery Sciences, Guangzhou - 510300, P. R. China \\ ${ }^{2}$ Key Laboratory of South China Sea Fishery Resources Exploitation and Utilisation, Ministry of Agriculture \\ Guangzhou - 510300, P. R. China \\ ${ }^{3}$ College of Fisheries and Life Science, Shanghai Ocean University, Shanghai - 201 306, China \\ ${ }^{4}$ School of Biological Sciences, Flinders University, GPO Box 2100, Adelaide, SA 5001, Australia \\ e-mail: zhenhua.ma@hotmail.com
}

\begin{abstract}
This study evaluated the efficacy of Artemia nauplii enriched with three enhancement products as live feed for golden pompano Trachinotus ovatus larvae. Artemia were separately enriched with Nannochloropsis, Algamac $3080^{\circledR}$ and Spirulina and unenriched Artemia nauplii served as control feed. Growth and survival of fish larvae were affected significantly $(p<0.05)$ by the enrichment products. Highest specific growth rate was obtained when fish were fed with Artemia nauplii enriched with Algamac 3080 and the lowest growth rate in fish fed with unenriched or spirulina enriched Artemia nauplii. Highest survival was obtained in groups fed with unenriched or Nannochloropsis enriched Artemia nauplii. Feeding with enriched Artemia nauplii also helped to reduce incidence of skeletal malformation during larval phase. Significantly lower $(\mathrm{p}<0.05)$ vertebral column malformation was observed when fish were fed with spirulina enriched Artemia nauplii. The highest docosahexaenoic acid (DHA)/eicosapentaenoic acid (EPA) ratio in Artemia was obtained when Artemia nauplii were enriched with Algamac 3080 and the lowest in unenriched Artemia nauplii. Results of the study indicated that the enrichment protocols attempted for Artemia nauplii significantly $(\mathrm{p}<0.05)$ helped to enhance the growth, survival and quality of golden pompano larvae.
\end{abstract}

Keywords: Artemia nauplii, Deformities, Enrichment, Golden pompano, Growth, Survival

\section{Introduction}

Artemia nauplii are widely used as live feed in marine fish larval rearing. The lack of n-3 highly unsaturated fatty acids in newly hatched Artemia makes it necessary to find suitable nutrient formula to enrich Artemia nauplii before feeding to fish larvae (Monroig et al., 2006). As the nutrient content of live feed can be altered through feeding manipulation (Watanabe et al., 1983; Koven et al., 1989), the method of live feed enrichment is critical to the growth and survival of fish larvae (Rainuzzo et al., 1997). Evidence has clearly indicated that the nutrient content of Artemia nauplli vary between enrichment formulations (Monroig et al., 2006), but the response of fish larvae to various enrichment formulations are species specific. Although the use of nutritionally enhanced Artemia nauplii can improve fish growth and survival, its impact on deformity is not clear, especially on new candidate species in aquaculture.

Golden pompano Trachinotus ovatus (Carangidae) has been identified as a potential candidate species for aquaculture owing to its fast growth, high flesh quality and suitability for cage culture. The life cycle of golden pompano has been closed in captivity and several other key aspects, such as food and feeding, development of the larval digestive system and weaning have been successfully explored (Ma et al., 2014; 2015a,b), Incidence of jaw and skeletal malformation during the early development stages has severely reduced the production efficiency of golden pompano (Ma et al., 2016). Our previous studies have identified the type, position and frequency of jaw and skeletal malformations in hatchery reared golden pompano larvae (Ma et al., 2016; Zheng et al., 2014). Nonetheless, factors causing skeletal malformation are still not clear in this species. The present study attempted to investigate the effect of feeding Artemia nauplii nutritionally enriched by three different methods, on the rearing performance and also on the incidence of skeletal malformations in larval golden pompano.

\section{Materials and methods}

Fertilized eggs of golden pompano were obtained from Guanghui Aquaculture Hatchery, Hainan Province, China and were transported to Lingshui Town and hatched in 5001 fiberglass incubators at $26^{\circ} \mathrm{C}$ with a hatching rate of $97.1 \pm 1.9 \%$ (mean $\pm \mathrm{SD})$. On 2 days post-hatching (DPH), 
larvae were stocked into four larval rearing tanks (1000 1) at a density of 60 fish $\mathrm{l}^{-1}$. Rearing tanks were supplied with filtered $(5 \mu \mathrm{m})$ seawater from the bottom of each tank through upwelling with a daily exchange rate of $200 \%$ tank volume. Water was discharged through an outlet screen $(300 \mu \mathrm{m})$ on the upper side of each tank and the screen was daily cleaned to reduce clogging. Two air stones were used in each tank to maintain dissolved oxygen level close to saturation.

Light intensity was maintained at 2400 lux and the light regime was controlled at $14 \mathrm{~h}$ light and $10 \mathrm{~h}$ dark. Salinity was maintained at $33 \pm 0.8 \%$ ond the rearing temperature was $26.5 \pm 1.0^{\circ} \mathrm{C}$ throughout the experiment. Rotifers Brachionus rotundiformis at a density of 10-20 rotifers $\mathrm{ml}^{-1}$ were used to feed the larvae from $2 \mathrm{DPH}$ to $12 \mathrm{DPH}$. The rotifers fed on baker's yeast were enriched with the DHA protein Selco (INVE Aquaculture, USA) and kept ready $12 \mathrm{~h}$ before adding into the larval rearing tanks. Instant microalgal paste (Nannocholoropsis sp., Qingdao Hong Bang Biological Technology Co Ltd., China) was also added into larval fish tanks to create a green-water background. On the morning of $11 \mathrm{DPH}$, fish larvae were restocked into larval rearing tanks $(12,5001$ capacity) at a density of 20 fish $\mathrm{l}^{-1}$. Rearing conditions were similar to the previous phase.

Feeding experiment included four dietary treatments, with three replicates each. Artemia nauplii were enriched with either of the three products viz., (i) instant microalgal paste, (ii) Algamac 3080® (Aquafauna, USA), (iii) Spirulina (Fengchan feeds, Tianjin, China) and (iv) Artemia nauplii without enrichment served as control. In each treatment, Artemia nauplii were enriched with the respective product following the manufacturers' instructions. The nauplii were fed to fish in different treatment groups from $11 \mathrm{DPH}$ to $27 \mathrm{DPH}$. Artemia nauplii were first introduced at 0.2 nauplii $\mathrm{ml}^{-1}$ on $11 \mathrm{DPH}$ and then added with a daily increment of $90 \%$ by number. Tank bottom was siphoned daily to remove dead fish and faeces.

Fish growth was assessed in terms of specific growth rate (SGR) as \% day ${ }^{-1}$ (Hopkins, 1992): $\mathrm{SGR}=100 \times\left(\operatorname{Ln}\left(S L_{f}\right)-\operatorname{Ln}\left(S L_{i}\right)\right) / D t$, where $S L_{f}$ and $S L_{i}$ are the final and initial total length $(\mathrm{mm})$, respectively, and $D t$ is the time interval (days) between samplings. On termination of the experiment, fish in each rearing tank were harvested and counted for the final survival estimation. Fifty fish from each tank were sampled for assessing growth as well as for incidence of skeletal malformations if any. Sampling for RNA and DNA estimation was also done on the last day of the study from each treatment in three replicates.
A total of 50 fish larvae were randomly collected from each rearing tank to examine the incidence of malformation. Fish were anaesthetised by overdosing of Aqui-S (AQUI-S, New Zealand) and fixed in $10 \%$ neutral buffered formalin. Jaw deformity was assessed by observing under a stereo microscope (Olympus SZ40, Japan) using the criteria described by Ma et al. (2016) and spine and caudal fin deformities were assessed and analysed according to the method described by Zheng et al. (2014).

For RNA and DNA estimation, ten fish were randomly collected from each of the rearing tanks. The anaesthetised fishes were pre-washed with distilled water to remove the salt on the body surface and then immediately preserved in liquid nitrogen. Frozen samples were dissected on an ice tray and muscle tissue samples were collected from the fishes. The RNA/DNA ratio was determined following the method described by Zehra and Khan (2013). Each of the pooled sample was weighed to the nearest $0.001 \mathrm{~g}$ and placed in a test tube in an ice slurry bath. Then the tissue samples were homogenised in 5\% trichloroacetic acid (TCA) at $90^{\circ} \mathrm{C}$ and then centrifuged at $5000 \mathrm{~g}$ for $20 \mathrm{~min}$. For RNA determination, $2.0 \mathrm{ml}$ of distilled water and $3.0 \mathrm{ml}$ of orcinol reagent were added to $1.0 \mathrm{ml}$ of supernatant. The reaction mixture was kept in boiling water for $20 \mathrm{~min}$ and the OD was measured at $660 \mathrm{~nm}$. For DNA determination, in $1 \mathrm{ml}$ of supernatant, $1.0 \mathrm{ml}$ of distilled water and $4.0 \mathrm{ml}$ of freshly prepared diphenylamine reagent were added. The mixed reagents were kept in a boiling water bath for $10 \mathrm{~min}$ and were measured at $600 \mathrm{~nm}$. Standard curves for RNA and DNA were developed using different concentrations of yeast RNA (Sigma-Aldrich, USA) and calf thymus DNA (SigmaAldrich, USA), respectively.

The nutritional content of Artemia nauplii was assessed on 11, 21, and 27 DPH. After enrichment, $4 \mathrm{~g}$ (wet weight) Artemia nauplii from each treatment in three replicates were collected and preserved in liquid nitrogen until analysis. At the end of the experiment, fish larvae ( $2 \mathrm{~g}$ wet weight) from each rearing tank were sampled for fatty acids analysis. Fatty acids were analysed at South China Sea Fisheries Research Institute, China following the method described by Ma and Qin (2014).

All percentage data were arcsine-transformed prior to analysis in this study. However, they were presented as untransformed values in the figures. The data are expressed as mean $\pm \mathrm{SD}$ and tested by one way ANOVA (PASW Statistics 18.0, Chicago, SPSS Inc.). When a significant treatment effect was found, Tukey's test was performed for multiple range comparisons with the level of significant difference set at $p<0.05$. All the data were tested for normality, homogeneity and independence to satisfy the assumptions of ANOVA. 


\section{Results and discussion}

The growth of golden pompano larvae was affected significantly by the enrichment products ( $\mathrm{p}<0.05$, Fig.1). The highest SGR was obtained in fish fed with Artemia nauplii enriched with Algamac 3080 and the lowest in fish fed unenriched and spirulina enriched Artemia nauplii. The SGR of fish was not significantly different when fish were fed with unenriched Artemia nauplii or spirulina enriched Artemia nauplii ( $\mathrm{p}>0.05)$. The highest survival was achieved in the treatment of unenriched Artemia and Nannochloropsis enriched Artemia $(\mathrm{p}<0.05$, Fig. 1) and the lowest survival was observed when fish were fed with Algamac 3080 enriched Artemia nauplii ( $<<0.05)$.

The RNA/DNA ratio of fish was significantly affected by the enrichment treatments $(\mathrm{p}<0.05$, Fig. 1). The highest RNA/DNA ratio was observed when fish were fed with Artemia nauplii enriched with Algamac 3080 $(\mathrm{p}<0.05)$. RNA/DNA ratio of fish fed spirulina enriched Artemia nauplii was significantly higher than fish fed with unenriched or Nannochloropsis enriched Artemia nauplii $(p<0.05)$ while the ratio was not significantly different when fish were fed with unenriched or Nannochloropsis enriched Artemia nauplii ( $\mathrm{p}>0.05)$.

Nutritional enhancement was found to have effect on incidence of skeletal malformation in fish during Artemia nauplii feeding phase (Fig. 2). Incidence of skeletal malformation was lower when fish were fed with nutrient enhanced Artemia nauplii. Significantly lower vertebral column malformation was observed when fish were fed with spirulina enriched Artemia nauplii ( $<<0.05$, Fig. 2). Caudal vertebra malformation was not significantly different between fish fed unenriched, Nannochloropsis enriched and Algamac 3080 enriched Artemia nauplii ( $>00.05$ ). The hypural malformation of fish fed Algamac

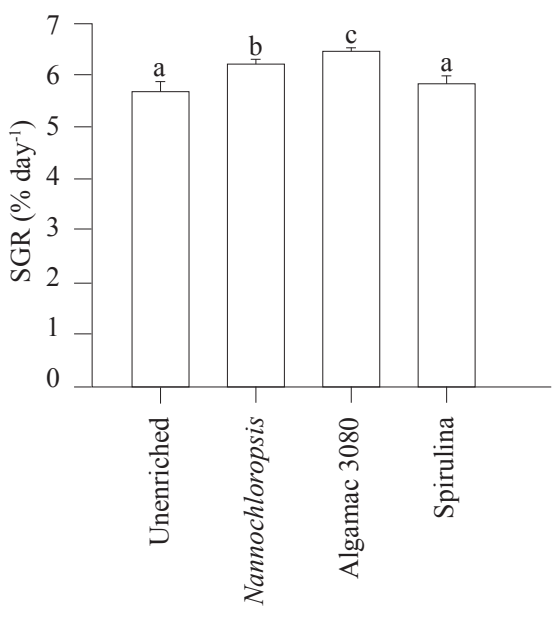

(a)

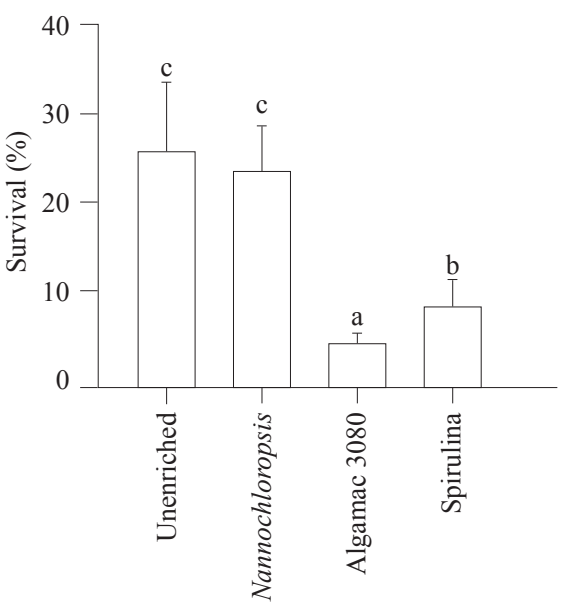

(b)

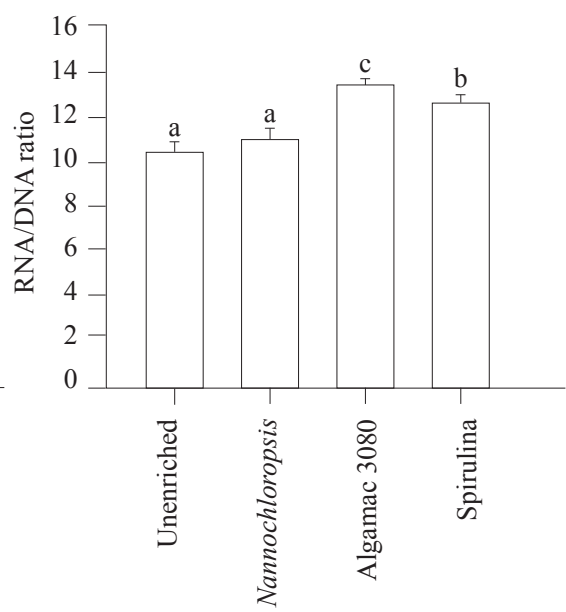

(c)

Fig. 1. Growth (a), survival (b) and RNA/DNA ratio (c) of golden pompano larvae in four enrichment treatments on 27 DPH. (Different letters represent significant differences at $\mathrm{p}<0.05$ )

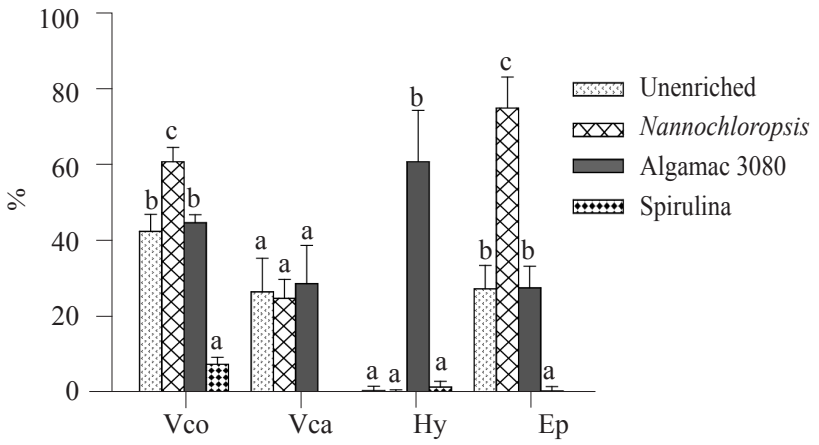

(a)

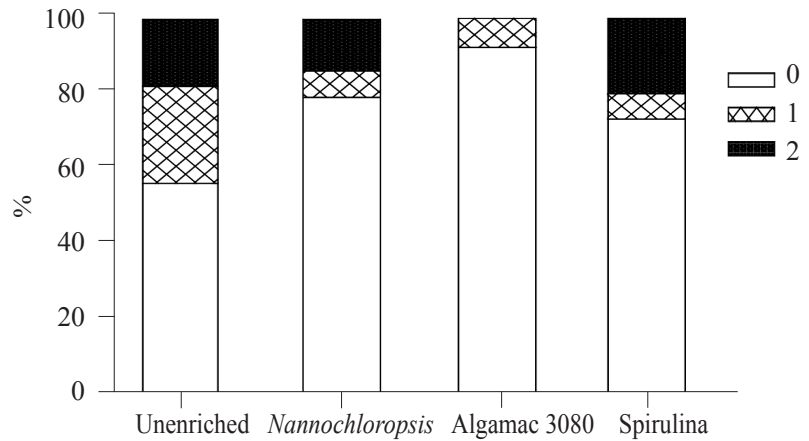

(b)

Fig. 2. Percentage incidence of vertebral column (Vco), caudal vertebra (Vca), hypural (Hy) and epural (Ep) malformations of golden pompano larvae in four enrichment treatments on 27 DPH. "0" - normal fish; "1" - light deformity, "2" - severe deformity. (Different letters represent significant differences at $\mathrm{p}<0.05$ ) 
3080 enriched Artemia nauplii was significantly higher than that in other treatments $(p<0.05$, Fig. 2). Epural malformation was observed to be highest when fish were fed with Nannochloropsis enriched Artemia nauplii and the lowest malformation was achieved when fish were fed with spirulina enriched Artemia nauplii (p<0.05, Fig. 2).

The specific fatty acid composition in Artemia nauplii significantly varied between treatments (Table 1). The amount of EPA (20:5n-3) in the Artemia nauplii enriched with Nannochloropsis (8.49\%) was significantly higher than that enriched with spirulina $(6.31 \%)$ and unenriched Artemia nauplii ( $\mathrm{p}<0.05$, Table 1$)$. The EPA was not significantly different between the treatments of Nannochloropsis and Algamac 3080 or between the treatments of Algamac 3080, spirulina and unenrichment $(\mathrm{p}>0.05)$. After enrichment, the highest amount of DHA (22: 6n-3) was obtained in Artemia nauplii enriched with Algamac $3080(2.56 \%, \mathrm{p}<0.05)$ and the lowest DHA level was observed in unenriched Artemia nauplii. After enrichment, the DHA/EPA ratio improved in all the enrichment treatments and the highest DHA/EPA was observed in the treatment of Algamac $3080(0.36, p<0.05)$. Similarly, the DHA/ARA (arachidoninc acid) ratio has improved after enrichment but no significant differences were found between those enrichment treatments ( $p>0.05$ ). After enrichment the EPA/ARA in Artemia nauplii improved only in the treatment of Nannochloropsis (Table 1, $\mathrm{p}<0.05$ ).

At the end of this experiment, the EPA in fish larvae varied between treatments. The highest EPA level of fish larvae was found in the treatment of Algamac 3080 $(9.02 \%, p<0.05$, Table 2) and the lowest was observed in the treatment of spirulina $(2.89 \%, \mathrm{p}<0.05$, Table 2$)$. The highest DHA level in fish larvae was observed in the treatment of Algamac 3080 (5.88\%) and Nannochloropsis $(4.73 \%)$ and lowest DHA level was found in the unenriched $(1.52 \%)$ and spirulina enriched treatments (2.67\%). The highest DHA/EPA ratio of fish larvae was observed in the treatment of Nannochloropsis (1.09) while the highest EPA/ARA ratio in fish larvae was observed in the treatment of Algamac 3080 (7.20) and the highest DHA/ARA ratio in fish was observed in the treatment of Algamac 3080 (4.68, Table 2).

In marine fish larvae both DHA and EPA in the diet are essential for fish growth (Rezek et al., 2010). Improved fish growth with increasing levels of dietary DHA has been observed in species such as yellowtail, Seiola quiqueradiata (Furuita et al., 1996), striped jack Caranx vinctus (Takeuchi et al., 1996) and Japanese flounder Paralichthys olivaceus (Izquierdo et al., 1992). Previous studies have clearly demonstrated that the growth response of fish larvae to different enrichment

Table 1. Fatty acid composition (\% of total fatty acids) of enriched and unenriched Artemia nauplii

\begin{tabular}{|c|c|c|c|c|}
\hline Fatty acid & Unenriched & Nannochloropsis & Algmac 3080 & Spirulina \\
\hline 14:0 & $1.14 \pm 0.21^{\mathrm{a}}$ & $0.80 \pm 0.10^{\mathrm{a}}$ & $1.18 \pm 0.32^{\mathrm{a}}$ & $0.94 \pm 0.07^{\mathrm{a}}$ \\
\hline $16: 0$ & $16.71 \pm 2.4^{\mathrm{a}}$ & $12.13 \pm 0.55^{\mathrm{a}}$ & $18.74 \pm 4.68^{\mathrm{a}}$ & $13.46 \pm 0.80^{\mathrm{a}}$ \\
\hline $16: 1 n-7$ & $0.44 \pm 0.05^{\mathrm{b}}$ & $0.51 \pm 0.09^{c}$ & $0.25 \pm 0.24^{\mathrm{a}}$ & $0.52 \pm 0.01^{\mathrm{c}}$ \\
\hline 18:0 & $5.88 \pm 0.52^{\mathrm{ab}}$ & $6.12 \pm 0.24^{b}$ & $6.42 \pm 0.44^{b}$ & $5.1 \pm 0.14^{\mathrm{a}}$ \\
\hline $18: 1 n-9$ & $9.27 \pm 0.74^{\mathrm{a}}$ & $11.71 \pm 0.72^{\mathrm{b}}$ & $9.74 \pm 1.48^{\mathrm{b}}$ & $9.59 \pm 0.32^{\mathrm{ab}}$ \\
\hline $18: 1 n-7$ & $19.44 \pm 2.1^{\mathrm{a}}$ & $21.83 \pm 1.75^{\mathrm{a}}$ & $19.87 \pm 1.55^{\mathrm{a}}$ & $20.45 \pm 0.19^{\mathrm{a}}$ \\
\hline $18: 2 n-6$ & $2.62 \pm 0.41^{\mathrm{ab}}$ & $2.82 \pm 0.30^{\mathrm{ab}}$ & $2.01 \pm 0.86^{\mathrm{a}}$ & $3.74 \pm 0.22^{\mathrm{b}}$ \\
\hline $18: 3 n-3$ & $0.32 \pm 0.11^{\mathrm{a}}$ & $0.80 \pm 0.45^{\mathrm{ab}}$ & $0.32 \pm 0.10^{\mathrm{a}}$ & $0.91 \pm 0.04^{b}$ \\
\hline 20:1n-9 & $0.61 \pm 0.04^{b}$ & $0.43 \pm 0.03^{\mathrm{a}}$ & $0.35 \pm 0.20^{\mathrm{a}}$ & $0.62 \pm 0.09^{b}$ \\
\hline $20: 4 n-6$ (ARA) & $1.22 \pm 0.10^{\mathrm{ab}}$ & $1.16 \pm 0.03^{\mathrm{a}}$ & $1.30 \pm 0.07^{\mathrm{b}}$ & $1.10 \pm 0.10^{\mathrm{a}}$ \\
\hline $20: 5 n-3$ (EPA) & $6.28 \pm 0.87^{\mathrm{a}}$ & $8.49 \pm 0.49^{b}$ & $7.23 \pm 1.00^{\mathrm{ab}}$ & $6.31 \pm 0.46^{\mathrm{a}}$ \\
\hline 22:6n-3 (DHA) & $0.45 \pm 0.06^{\mathrm{a}}$ & $1.87 \pm 0.08^{b}$ & $2.56 \pm 0.31^{\mathrm{c}}$ & $1.74 \pm 0.24^{b}$ \\
\hline DHA/EPA & $0.07 \pm 0.00^{\mathrm{a}}$ & $0.22 \pm 0.02^{\mathrm{b}}$ & $0.36 \pm 0.09^{\mathrm{c}}$ & $0.28 \pm 0.06^{\mathrm{b}}$ \\
\hline EPA/ARA & $5.10 \pm 0.31^{\mathrm{a}}$ & $7.31 \pm 0.23^{b}$ & $5.62 \pm 1.07^{\mathrm{a}}$ & $5.75 \pm 0.10^{\mathrm{a}}$ \\
\hline DHA/ARA & $0.37 \pm 0.02^{\mathrm{a}}$ & $1.61 \pm 0.11^{\mathrm{b}}$ & $1.96 \pm 0.13^{\mathrm{b}}$ & $1.62 \pm 0.37^{\mathrm{b}}$ \\
\hline Total n-3 & $7.05 \pm 1.04^{\mathrm{a}}$ & $11.16 \pm 0.86^{c}$ & $10.11 \pm 0.79^{b}$ & $8.96 \pm 0.26^{\mathrm{b}}$ \\
\hline Total n-6 & $3.84 \pm 0.05^{\mathrm{ab}}$ & $3.98 \pm 0.33 \mathrm{a}^{\mathrm{b}}$ & $3.31 \pm 0.79^{\mathrm{a}}$ & $4.84 \pm 0.32^{\mathrm{b}}$ \\
\hline Total n-7 & $19.88 \pm 2.15^{\mathrm{a}}$ & $22.35 \pm 1.84^{\mathrm{a}}$ & $20.11 \pm 1.78^{\mathrm{a}}$ & $20.97 \pm 0.20^{\mathrm{a}}$ \\
\hline Total n-9 & $9.87 \pm 0.70^{\mathrm{a}}$ & $12.14 \pm 0.75^{b}$ & $10.09 \pm 1.28^{\mathrm{a}}$ & $10.21 \pm 0.23^{\mathrm{a}}$ \\
\hline Total saturated & $23.73 \pm 3.13^{\mathrm{a}}$ & $19.05 \pm 0.22^{\mathrm{a}}$ & $26.34 \pm 5.44^{\mathrm{a}}$ & $19.50 \pm 0.73^{\mathrm{a}}$ \\
\hline Total poly unsaturated & $40.64 \pm 4.39^{\mathrm{a}}$ & $49.63 \pm 3.78^{\mathrm{a}}$ & $43.61 \pm 4.63^{\mathrm{a}}$ & $44.97 \pm 0.60^{\mathrm{a}}$ \\
\hline
\end{tabular}

Values bearing different superscripts are significantly different $(\mathrm{p}<0.05)$. 
Table 2. Fatty acid composition (\% of total fatty acids) of golden pompano larvae fed on enriched/unenriched Artemia nauplii

\begin{tabular}{lllll}
\hline Fatty acid & Unenriched & Nannochloropsis & Algmac 3080 & Spirulina \\
\hline $14: 0$ & $1.01 \pm 0.40^{\mathrm{b}}$ & $0.92 \pm 0.40^{\mathrm{ab}}$ & $1.14 \pm 0.01^{\mathrm{b}}$ & $0.41 \pm 0.18^{\mathrm{a}}$ \\
$16: 0$ & $16.91 \pm 4.20^{\mathrm{a}}$ & $15.77 \pm 2.83^{\mathrm{a}}$ & $15.57 \pm 0.88^{\mathrm{a}}$ & $16.91 \pm 4.20^{\mathrm{a}}$ \\
$16: 1 \mathrm{n}-7$ & $0.36 \pm 0.05^{\mathrm{a}}$ & $0.36 \pm 0.01^{\mathrm{a}}$ & $0.58 \pm 0.01^{\mathrm{b}}$ & $0.28 \pm 0.06^{\mathrm{a}}$ \\
$18: 0$ & $7.52 \pm 0.30^{\mathrm{ab}}$ & $8.75 \pm 1.44^{\mathrm{b}}$ & $6.23 \pm 0.28^{\mathrm{ab}}$ & $5.80 \pm 1.58^{\mathrm{a}}$ \\
$18: 1 \mathrm{n}-9$ & $12.70 \pm 1.21^{\mathrm{b}}$ & $11.86 \pm 1.40^{\mathrm{b}}$ & $12.25 \pm 0.66^{\mathrm{b}}$ & $7.98 \pm 2.27^{\mathrm{a}}$ \\
$18: 1 \mathrm{n}-7$ & $16.70 \pm 0.52^{\mathrm{b}}$ & $15.91 \pm 1.32^{\mathrm{b}}$ & $23.88 \pm 0.71^{\mathrm{c}}$ & $10.59 \pm 2.81^{\mathrm{a}}$ \\
$18: 2 \mathrm{n}-6$ & $2.57 \pm 0.50^{\mathrm{b}}$ & $2.25 \pm 0.11^{\mathrm{ab}}$ & $3.08 \pm 0.11^{\mathrm{c}}$ & $1.73 \pm 0.33^{\mathrm{a}}$ \\
$18: 3 \mathrm{n}-3$ & $0.23 \pm 0.03^{\mathrm{a}}$ & $0.20 \pm 0.05^{\mathrm{a}}$ & $1.08 \pm 0.66^{\mathrm{b}}$ & $0.17 \pm 0.01^{\mathrm{a}}$ \\
$20: 1 \mathrm{n}-9$ & - & - & - \\
$20: 4 \mathrm{n}-6$ (ARA) & $0.14 \pm 0.14$ & $1.78 \pm 0.16^{\mathrm{b}}$ & $1.26 \pm 0.05^{\mathrm{a}}$ & $1.26 \pm 0.35^{\mathrm{a}}$ \\
$20: 5 \mathrm{n}-3$ (EPA) & $1.80 \pm 0.18^{\mathrm{b}}$ & $4.40 \pm 0.49^{\mathrm{b}}$ & $9.02 \pm 0.03^{\mathrm{c}}$ & $2.89 \pm 0.58^{\mathrm{a}}$ \\
$22: 6 \mathrm{n}-3$ (DHA) & $4.56 \pm 0.84^{\mathrm{b}}$ & $4.73 \pm 0.08^{\mathrm{b}}$ & $5.88 \pm 0.65^{\mathrm{b}}$ & $2.67 \pm 1.18^{\mathrm{a}}$ \\
DHA/EPA & $1.52 \pm 0.06^{\mathrm{a}}$ & $1.09 \pm 0.14^{\mathrm{c}}$ & $0.65 \pm 0.07^{\mathrm{ab}}$ & $0.89 \pm 0.23^{\mathrm{bc}}$ \\
EPA/ARA & $0.34 \pm 0.05^{\mathrm{a}}$ & $2.46 \pm 0.05^{\mathrm{a}}$ & $7.20 \pm 0.28^{\mathrm{b}}$ & $2.35 \pm 0.19^{\mathrm{a}}$ \\
DHA/ARA & $2.51 \pm 0.21^{\mathrm{a}}$ & $2.68 \pm 0.29^{\mathrm{c}}$ & $4.68 \pm 0.35^{\mathrm{d}}$ & $2.01 \pm 0.37^{\mathrm{b}}$ \\
Total n-3 & $0.85 \pm 0.05^{\mathrm{a}}$ & $9.32 \pm 0.45^{\mathrm{b}}$ & $15.98 \pm 1.26^{\mathrm{c}}$ & $5.73 \pm 1.77^{\mathrm{a}}$ \\
Total n-6 & $6.30 \pm 0.92^{\mathrm{a}}$ & $4.03 \pm 0.27^{\mathrm{a}}$ & $4.33 \pm 0.15^{\mathrm{b}}$ & $2.99 \pm 0.68^{\mathrm{a}}$ \\
Total n-9 & $4.37 \pm 0.68^{\mathrm{b}}$ & $11.88 \pm 1.40^{\mathrm{b}}$ & $12.25 \pm 0.66^{\mathrm{b}}$ & $7.98 \pm 2.27^{\mathrm{a}}$ \\
Total n-7 & $12.70 \pm 1.21^{\mathrm{b}}$ & $16.26 \pm 1.32^{\mathrm{b}}$ & $24.46 \pm 0.72^{\mathrm{c}}$ & $10.87 \pm 2.87^{\mathrm{a}}$ \\
Total saturated & $17.06 \pm 0.57^{\mathrm{b}}$ & $25.44 \pm 4.67^{\mathrm{a}}$ & $22.94 \pm 1.17^{\mathrm{a}}$ & $23.11 \pm 2.45^{\mathrm{a}}$ \\
Total poly unsaturated & $25.43 \pm 4.89^{\mathrm{a}}$ & $37.09 \pm 2.95^{\mathrm{b}}$ & $47.99 \pm 1.5^{\mathrm{c}}$ & $24.66 \pm 6.99^{\mathrm{a}}$ \\
\hline
\end{tabular}

Values bearing different superscripts are significantly different $(\mathrm{p}<0.05)$.

products varied among species. For instance, the growth of larvae of striped bass Morone saxatilis and gilthead seabream Sparus aurata was not affected by feeding Artemia nauplii enriched with Algamac 2000 or PL-Cr (DHA-rich phospholipid extract of Crypthecodinium sp.), but the growth of Hippoglossus hippoglossus larvae fed Artemia nauplii enriched with DHA Seleco was lower than the growth of larvae fed with PL-Cr (Harel et al., 2002). In the present study, fish growth was enhanced when fish larvae were fed with Artemia nauplii enriched with Algamac 3080 or Nannochloropsis. The best fish SGR was achieved in the treatment of Algamac 3080, which is consistent with the higher dietary DHA levels observed in the live feed in this treatment. As a sensitive growth and nutritional condition indicator (Islam and Tanaka, 2005; Zehra and Khan, 2013), the RNA/DNA ratio indicated that better growth performance occurred in the treatment of Algamac 3080. However, fish growth in the treatments of Nannochloropsis and spirulina is not consistent with their RNA/DNA ratios and dietary DHA levels. As Faulk and Holt (2005) suggested, such inconsistency may be possibly due to the difference in the protein content or amino acid profiles of live prey fed with different enrichments.

Highly unsaturated fatty acids, especially EPA, DHA and ARA are essential for growth, development and survival in marine fish (Sargent et al., 1999; Cahu et al., 2003; Rezek et al., 2010). To develop lipid enriched food for fish larvae, the requirements of essential fatty acids in fish larvae have been extensively studied using live prey enriched with different oils and micro-nutrients, aiming to increase the essential fatty acids content in live prey (Sargent et al., 1997; Takeuchi, 1997; Izquierdo et al., 2000). However, excessive dietary lipid content or unbalanced lipid class composition has been found to be associated with poor growth and skeletal malformation in species such as Seriola lalandi (Ma and Qin, 2014), S. aurata (Salhi et al., 1999), H. hippoglossus (Olsen et al., 2000) and Atlantic cod Gadus morhua (Kjorsvik et al., 2009). In the present study, enrichment did not change the DHA/ARA ratio, but a higher DHA/EPA ratio $(0.36: 1)$ was achieved by enriching Artemia nauplii with Algamac 3080. The high DHA/EPA ratio observed in the Algamac 3080 treatment led to fast growth but lower survival. On the contrary, a better survival was obtained in the unenriched and Nannochloropsis treatments where the DHA/EPA ratio was 0.07:1 - 0.22:1. Low fish survival in the Algamac 3080 treatment supports the claim in a previous study that a high DHA content and a high DHA/ EPA ratio may reduce larval fish survival (Planas and Cunha, 1999) as unbalanced lipid class composition in the diet affects the digestion and absorption of fatty acids in fish larvae (Salhi et al., 1997; 1999).

Incidence of skeletal malformation in fish in marine aquaculture is a recurrent issue (Ma and Qin, 2014; Ma et al., 2016) and skeletal malformation negatively affects fish quality in commercial production via suppressing fish growth and survival (Andrades et al., 1996; Boglione et al., 2001). The abnormalities can have sub-lethal 
(Barahona-Fernandes, 1982; Cobcroft et al., 2001) or lethal effects on fish larvae (Boglione et al., 2013) as the impaired mouth would affect the efficiency of food ingestion (Pittman et al., 1989), while notochord anomalies in newly hatched larvae can severely affect swimming (Boglione et al., 2013).

The relationship between the deficiency of essential fatty acids and the development of skeletal anomalies is poorly understood (Boglione et al., 2013). Hamre et al. (2002) suggested that the abnormal development of fish larvae may be triggered by insufficient dietary n-3 HUFA in Artemia nauplii. Recent evidence has demonstrated that fatty acids such as DHA, EPA and ARA play important role in bone development and a 50\% reduction of deformed fish was observed when fish larvae were fed with higher levels of dietary DHA (Izquierdo et al., 2010). In the present study, incidence of skeletal malformation was lower in the treatment of Algamac 3080 which is consistent with high DHA levels in the feeds. This indicates that a dietary DHA level of $2.56 \%$ may be suitable for the skeletal development of golden pompano larvae.

The vertebral column and caudal complex malformations are the most frequently reported body deformity in commercial cultured species (Negm et al., 2013). At present, little is known on the causes triggering the deformity in the caudal complex (Haga et al., 2011). Vertebral deformities are often associated with swim bladder abnormality (Chatain, 1994; Daoulas et al., 1991), but vitamin A deficiency can also induce vertebral column deformities (Negm et al., 2013). In the present study, the highest vertebral column (Vco) malformation (60.9\%) and epural (Ep) malformation (75.1\%) were observed in the treatment of Nannochloropsis, and lowest Vco malformation (7.7\%) and Ep malformation $(0.7 \%)$ were found in the treatment of spirulina. Significantly higher hypural malformation $(61.0 \%)$ was observed in the treatment of Algamac 3080, compared to other treatments. This may suggest that nutrient enhancement in the Artemia nauplii affects the vertebral deformities and the impact of nutritional components in Artemia nauplii on larval fish development warrants further study.

In summary, the present study examined the effects of nutritional enhancement on the rearing performance and skeletal malformation of larval golden pompano during the Artemia nauplii feeding phase. Results of the present study demonstrated that nutritional enhancement in Artemia nauplii can significantly affect the performance of golden pompano larvae. Future study should focus on refining the optimum levels of dietary enrichment in golden pompano larvae to improve growth and survival, and to decrease skeletal malformation of fish larvae.

\section{Acknowledgements}

This project was funded by Pearl River S\&T Nova Program of Guangzhou (2016100010), Special Scientific Research Funds for Central Non-profit Institutes, South China Sea Fisheries Research Institute, Chinese Academy of Fishery Sciences (2014YJ01) and China Postdoctoral Science Foundation (2013M542220, 2014T70831).

\section{References}

Andrades, J. A., Becerra, J. and Fernandez-Llebrez, P. 1996 Skeletal deformities in larval, juvenile and adult stages of cultured gilthead seabream (Sparus aurata L.). Aquaculture, 141(1-2): 1-11.

Barahona-Fernandes, M. H. 1982. Body deformation in hatchery reared European seabass Dicentrarchus labrax (L). types, prevalence and effect on fish survival. J. Fish Biol., 21: $239-249$.

Boglione, C., Gagliardi, F., Scardi, M. and Cataudella, S. 2001. Skeletal descriptors and quality assessment in larvae and post-larvae of wild-caught and hatchery-reared gilthead seabream (Sparus aurata L. 1758). Aquaculture, 192: 1-22.

Boglione, C., Gisbert, E., Gavaia, P., Witten, P. E., Moren, M., Fontagne, S. and Koumoundouros, G. 2013. Skeletal anomalies in reared European fish larvae and juveniles. Part 2: main typologies, occurrences and causative factors. Rev. Aquac., 5: S121-S167.

Cahu, C., Zambonino Infante, J. and Takeuchi, T. 2003. Nutritional components affecting skeletal development in fish larvae. Aquaculture, 227(1-4): 245-258.

Chatain, B. 1994. Abnormal swimbladder development and lordosis in seabass (Dicentrarchus labrax) and seabream (Sparus auratus). Aquaculture, 119: 371-379.

Cobcroft, J. M., Pankhurst, P. M., Sadler, J. and Hart, P. R. 2001. Jaw development and malformation in cultured striped trumpeter Latris lineata. Aquaculture, 199: 267-282.

Daoulas, C., Economou, A. N. and Bantavas, I. 1991. Osteological abnormalities in laboratory reared seabass (Dicentrarchus labrax) fingerlings. Aquaculture, 97: 169-180.

Faulk, C. K. and Holt, G. J. 2005. Evaluation of fatty acid enrichment of live food for yellowtail snapper Ocyurus chrysurus larvae. J. World Aquac. Soc., 36: 271-281.

Ferguson, M. M. and Danzmann, R. G. 1998. Role of genetic markers in fisheries and aquaculture: useful tools or stamp collecting? Can. J. Fish. Aquat. Sci., 55: 1553-1563.

Furuita, H., Takeuchi, T., Watanabe, T., Fujimoto, H., Sekiya, S. and Imaizumi, K. 1996. Requirements of larval yellowtail for eicosapentaenoic acid, docosahexaenoic acid, and n-3 highly unsaturated fatty acid. Aquaculture, 62(3): 372-379.

Haga, Y., Du, S. J., Satoh, S., Kotani, T. and Fushimi, H. 2011. Analysis of the mechanism of skeletal deformity in fish 
larvae using a vitamin A induced bone deformity model. Aquaculture, 315: 26-33.

Hamre, K., Opstad, I., Espe, M., Solbakken, J., Hemre, G. I. and Pittman, K. 2002. Nutrient composition and metamorphosis success of Atlantic halibut (Hippoglossus hippoglossus, L.) larvae fed natural zooplankton or Artemia. Aquac. Nutr., 8: $139-148$.

Harel, M., Koven, W., Lein, I., Bar, Y., Behrens, P., Stubblefield, J., Zohar, Y. and Place, A. 2002. Advanced DHA, EPA, and ARA enrichment materials for marine aquaculture using single cell heterotrophs. Aquaculture, 213: 347-362.

Hopkins, K. D. 1992. Reporting fish growth: a review of the basics. J. World Aquac. Soc., 23: 173-179.

Islam, M. S. and Tanaka, M. 2005. Nutritional condition, starvation status and growth of early juvenile Japanese seabass (Lateolabrax japonicus) related to prey distribution and feeding in the nursery ground. J. Exp. Mar. Biol. Ecol., 323: $172-183$

Izquierdo, M. S., Arakawa, T., Takeuchi, T., Haroun, R. and Watanabe, T. 1992. Effect of n-3 HUFA levels in Artemia on growth of larval Japanese flounder (Paralichthys olivaceus). Aquaculture, 105(1): 73-82.

Izquierdo, M. S., Socorro, J., Arantzamendi, L. and HernandezCruz, C. M. 2000. Recent advances in lipid nutrition in fish larvae. Fish Physiol. Biochem., 22(2): 97-107.

Izquierdo, M. S., Socorro, J. and Roo, J. 2010. Studies on the appearance of skeletal anomalies in red porgy: effect of culture intensiveness, feeding habits and nutritional quality of live preys. J. Appl. Ichth., 26: 320-326.

Kjorsvik, E., Olsen, C., Wold, P. A., Hoehne-Reitan, K., Cahu, C. L., Rainuzzo, J., Olsen, A. I., Oie, G. and Olsen, Y. 2009. Comparison of dietary phospholipids and neutral lipids on skeletal development and fatty acid composition in Atlantic cod (Gadus morhua). Aquaculture, 294(3-4): 246-255.

Koven, W., van Anholt, R., Lutzky, S., Atia, I. B., Nixon, O., Ron, B. and Tandler, A. 2003. The effect of dietary arachidonic acid on growth, survival and cortisol levels in different age gilthead seabream larvae (Sparus auratus) exposed to handling or daily salinity change. Aquaculture, 228: $307-320$

Koven, W. M., Kissil, G. W. and Tandler, A. 1989. Lipid and n-3 requirement of Sparus aurata larvae during starvation and feeding. Aquaculture, 79: 185-191.

Koven, W. M., Tandler, A., Sklan, D. and Kissil, G. W. 1993. The association of eicosapentaenoic and docosahexaenoic acids in the main phospholipids of different-age Sparus aurata larvae with growth. Aquaculture, 116(1): 71-82.

Ma, Z., Guo, H., Zhang, D., Hu, C. Q. and Jiang, S. 2015a. Food ingestion, consumption, and selectivity of pompano, Trachinotus ovatus (Linnaeus 1758) under different rotifer densities. Aquac. Res., 46: 2593-2603.
Ma, Z., Guo, H., Zheng, P., Wang, L., Jiang, S., Qin, J. G. and Zhang, D. 2014. Ontogenetic development of digestive functionality in golden pompano Trachinotus ovatus (Linnaeus, 1758). Fish Physiol. Biochem., 40(4): 1157-1167.

Ma, Z. and Qin, J. G. 2014. Replacement of fresh algae with commercial formulae to enrich rotifers in larval rearing of yellowtail kingfish Seriola lalandi (Valenciennes, 1833). Aquac. Res., 45: 949-960.

Ma, Z., Zheng, P., Guo, H., Zhang, N., Jiang, S., Zhang, D. and Qin, J. G. 2016. Jaw malformation of hatchery reared golden pompano Trachinotus ovatus (Linnaeus, 1758) larvae. Aquac. Res., 47: 1141-1149.

Ma, Z., Zheng, P., Guo, H., Zhang, N., Wang, L., Jiang, S., Qin, J. G. and Zhang, D. 2015b. Effect of weaning time on the performance of Trachinotus ovatus (Linnaeus, 1758) larvae. Aquac. Nutr., 21(5): 670-678.

Monroig, O., Navarro, J. C., Amat, F., Gonzalez, P., Bermejo, A. and Hontoria, F. 2006. Enrichment of Artemia nauplii in essential fatty acids with different types of liposomes and their use in the rearing of gilthead sea bream (Sparus aurata) larvae. Aquaculture, 251(2-4): 491-508.

Negm, R. K., Cobcroft, J. M., Brown, M. R., Nowak, B. F. and Battaglene, S. C. 2013. The effects of dietary vitamin A in rotifers on the performance and skeletal abnormality of striped trumpeter Latris lineata larvae and post-larvae. Aquaculture, 404-405: 105-115.

Olsen, A. I., Attramadal, Y., Reitan, K. I. and Olsen, Y. 2000 Food selection and digestion characteristics of Atlantic halibut (Hippoglossus hippoglossus) larvae fed cultivated prey organisms. Fish Physiol. Biochem., 181: 293-310.

Pittman, K., Skiftesvik, A. B. and Harboe, T. 1989. Effect of temperature on growth rates and organogenesis in the larvae of halibut (Hippoglossus hippoglossus L.). J World Aquac. Soc., 191: 421-430.

Planas, M. and Cunha, I. 1999. Larviculture of marine fish: problems and perspectives. Aquaculture, 177(1-4): 171-190.

Rainuzzo, J. R., Reitan, K. I. and Olsen, Y. 1997. The significance of lipids at early stages of marine fish: a review. Aquaculture, 155(1-4): 103-115.

Rezek, T. C., Watanabe, W. O., Harel, M. and Seaton, P. J. 2010. Effects of dietary docosahexaenoic acid (22:6n-3) and arachidonic acid (20:4n-6) on the growth, survival, stress resistance and fatty acid composition in black seabass Centropristis striata (Linnaeus 1758) larvae. Aquac. Res., 41: 1302-1314.

Salhi, M., Hernandez-Cruz, C. M., Bessonart,, M., Izquierdo, M. S and Fernandez-Palacios, H. 1999. Effect of different dietary polar lipid levels and different n-3 HUFA content in polar lipids on gut and liver histological structure of gilthead seabream (Sparus aurata) larvae. Aquaculture, 179(1-4): 253-263. 
Salhi, M., Izquierdo, M. S., Hernandez-Cruz, C. M., Socorro, J. and Fernandez-Palacios, H. 1997. The improved incorporation of polyunsaturated fatty acids and changes in liver structure in larval gilthead seabream fed on microdiets. J. Fish Biol., 51: 869-879.

Sargent, J., McEvoy, L., Estevez, A., Bell, G., Bell, M., Henderson, J. and Tocher, D. 1999. Lipid nutrition of marine fish during early development: current status and future directions. Aquaculture, 179(1-4): 217-229.

Sargent, J. R., McEvoy, L. A. and Bell, J. G. 1997. Requirements, presentation and sources of polyunsaturated fatty acids in marine fish larval feeds, 155(1-4): 117-127.

Takeuchi, T. 1997. Essential fatty acid requirements of aquatic animals with emphsis on fish larvae and figerlings. Rev. Fish. Sci., 5: 1-25.

Takeuchi, Y., Masuda, R., Ishizaki, Y., Watanabe, T., Kanematsu, M., Imaizumi, K. and Tsukamoto, K. 1996. Determination of the requirement of larval striped jack for eicosapentaenoic acid and docosahexaenoic acid using enriched Artemia nauplii, Fish. Sci., 62: 760-765.
Tocher, D. R., Mourente, G. and Sargent, J. R. 1997. The use of silages prepared from fish neural tissues as enrichers for rotifers (Brachionus plicatilis) and Artemia in the nutrition of larval marine fish. Fish. Sci., 148(2-3): 213-231.

Watanabe, T., Tamiya, T., Oka, A., Hirata, M., Kitajima, C. and Fujita, S. 1983. Improvement of dietary value of live foods for fish larvae by feeding them on n-3 highly unsaturated fatty acids and fat-soluble vitamins. Bull. Jap. Soc. Sci. Fish., 49: 471-479.

Zehra, S. and Khan, M. A. 2013. Dietary lysine requirement of fingerling Catla catla (Hamilton) based on growth, protein deposition, lysine retention efficiency, RNA/DNA ratio and carcass composition. Fish Physiol. Biochem., 39: 503-512.

Zheng, P., Ma, Z., Guo, H., Zhang, D., Fu, M., Zhang, N. and Jiang, S. 2014. Osteological ontogeny and malformations in larval and juvenile golden pompano Trachinotus ovatus (Linnaeus, 1758). Aquac. Res., 47(5): 1421-1431. 